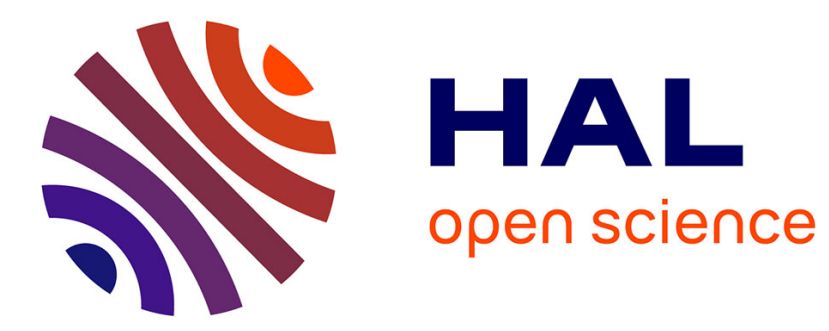

\title{
Supporting a virtual community of tutors in experience capitalising
}

\author{
Elise Garrot, Sébastien George, Patrick Prévôt
}

\section{To cite this version:}

Elise Garrot, Sébastien George, Patrick Prévôt. Supporting a virtual community of tutors in experience capitalising. International Journal of Web Based Communities, 2009, 5 (3), pp.407-427. hal-00392790

\section{HAL Id: hal-00392790 \\ https://hal.science/hal-00392790}

Submitted on 16 Dec 2011

HAL is a multi-disciplinary open access archive for the deposit and dissemination of scientific research documents, whether they are published or not. The documents may come from teaching and research institutions in France or abroad, or from public or private research centers.
L'archive ouverte pluridisciplinaire HAL, est destinée au dépôt et à la diffusion de documents scientifiques de niveau recherche, publiés ou non, émanant des établissements d'enseignement et de recherche français ou étrangers, des laboratoires publics ou privés. 


\title{
Supporting a Virtual Community of Tutors in Experience Capitalizing
}

\section{Élise Garrot*, Sébastien George and Patrick Prévôt}

\author{
LIESP Laboratory \\ INSA-Lyon, F-69621, France \\ E-mail: elise.garrot@insa-lyon.fr \\ E-mail: sebastien.george@insa-lyon.fr \\ E-mail: patrick.prevot@insa-lyon.fr \\ *Corresponding author
}

\begin{abstract}
Nowadays, Information and Communication Technologies change the way students learn. Many researches focus on the development of new forms of pedagogy and software for student learning. But ICT also involve changes in teachers' roles, which are not yet well defined in particular for on-line tutors. In this paper, we present new ways for tutors to define their own "professional identity", their functions and "good practices". By providing a platform to develop communities of practice of tutors, we aim at giving them the possibility to share knowledge, experiences and to refer to them in their day-today practice. We detail the interface to classify and retrieve experiences stored as knowledge in a database.
\end{abstract}

Keywords: Virtual Communities of Practice, On-line Tutor, Knowledge Management System, Information and Communication Technologies

Reference to this paper should be made as follows: Garrot, E., George, S. and Prévôt, P. (2008) 'Supporting a Virtual Community of Tutors in Experience Capitalizing', Int. J. Web Based Communities, Vol. X, No. Y, pp.000-000.

Biographical notes: Élise Garrot received in 2005 the Industrial Engineering Degree from INSA Lyon (National Institute of Applied Sciences, Engineering University in France) and the MS degree in Computer Science from the University of Lyon. She is currently a PhD candidate in Computer Science at the INSA of Lyon, in the LIESP Research Laboratory (informatics and information systems for the enterprise and production systems). Her research interests include tools to support virtual communities of practice, open and distance learning and assistance to human tutoring.

Sébastien George is an Associate Professor in the Department of Computer Science, INSA Lyon. He is a member of the LIESP Research Laboratory. He received his Doctoral Thesis from the University of Maine in France. There he designed and developed an environment dedicated to distant project-based learning. Then he did a postdoctoral fellowship at the TeleUniversity of Quebec in Canada. He joined INSA Lyon in 2002. His major fields of interest are computer supported collaborative learning, computer mediated communication and assistance to human tutoring in distance education.

Patrick Prévôt is Professor in the Industrial Engineering Department, INSA Lyon in France. Graduate Engineer, he has a doctorate in Science and is member of the LIESP Research Laboratory. He set up Industrial Engineering Department (Engineering University) in 1992, European Journal of Automation in 1996 and a Research Team about e-learning and serious games building in 1995. His major interest topics are: Serious game building, Author environment, Collaborative learning, Computer Human Interface, Cognitive psychology, Knowledge Management. He is author or co-author of fifteen serious games about Industrial Engineering. 


\section{Introduction}

With the development of technologies on Internet (e.g. forums, blogs or wikis), we observe the emergence of many web-based communities. Our research is focused on a specific type of community: Communities of Practice (CoPs), in which members share their practices to develop their knowledge and skills (Wenger, 1998). More precisely, we aim at developing a platform to support a global CoP of tutors that we define as educational actors who monitor learners in distance education.

In distance education, Information and Communication Technologies (ICT) involve new learning techniques, which are used by companies and universities with on-line courses and training. But it also involves a new definition and new roles for teachers, and particularly the tutor role. As we detail in first part, this new role is not yet well defined and tutors have many functions to assume, often without any help. That is why we suggest to consider them in a global CoP composed of interconnected CoPs in the frontiers of which they will exchange practices and experiences. By studying the specificities of tutors' role, we define requirements for a platform to support the CoP. We show the lack of adapted Web 2.0 software applications to respond to all these requirements and then we put forward an answer with the TE-Cap (Tutoring Experience Capitalization) platform. The development is based on an iterative process which allows to refine functionalities and the interface design. An important part of the work concerns the interface design as we consider that a simple interface easy to use is necessary if we want tutors to be able to store and retrieve resources (messages, useful documents and Web links). We present the results of an experiment conducted with twelve tutors with different background that lead us to make hypothesis on the requirements to support the participation among members of a CoP of tutors. We finally conclude with some questions involved by the experiment results.

\section{Research issues}

The increasing roles played by Internet and especially by ICT have changed the way we learn. Distance learning moved from a mail to an on-line mode. We emphasize benefits of this new form of education for students, like course individualization and flexibility in terms of space and time.

Houssaye (1988) represents relations between learner, teacher and knowledge, under the shape of the "educational triangle". This triangle brings out three educational styles (Faerber, 2002): the teacher-knowledge relation corresponds to the traditional education with knowledge transmission, the teacher-learner relation defines the emotional and psychological relation between these two actors and learner-knowledge relation represents the knowledge appropriation by learner. In traditional education, teacher often has a role of "transmitter of knowledge" and learners absorb a quantity of information, among which little will be transformed into knowledge.

Distance learning is based on several educational theories. According to Piaget (1978) or Vygotsky (1986), learners build knowledge by their own activity and by interactions with others. This educational theory emphasizes the fact that cognitive development results, on one hand, from the resolution of problems, from process of cognitive imbalance followed by restructuring (contribution of Piaget) and, on the other hand, of social interaction (contribution of Vygotsky) and in particular of collaboration between peers. In a constructivist approach, progress appears when learners in interaction disagree, the conflict being highlighted in the social interaction. It is named the "sociocognitive conflict" (Doise et al., 1975). The constructivist theories developed by Doise et al. (1984) considers learning as a personal experience towards knowledge, influenced by the social context in which it takes place. According to the socio-constructivist approach, interactions between learners play a dynamic role in individual learning.

Based on these theories, Faerber (2002) adapts the "educational triangle" (tutor, learner, knowledge) from face to face education to distance learning through a virtual environment. He adds two new components: (1) the group which he defines as an established set of learners and teacher(s) in interaction, sharing common objectives and (2) the virtual environment, in which and by which happen interactions. The environment offers tools which support interactions between actors or interactivity with cognitive contents. Thorpe (2002) also considers the "learning group" as a fourth component of the traditional triangle: "The potential to create extensive dialogues and interchanges electronically means that online teaching is often prioritising the learning group as the chief resource for learners and the focus for the tutor, rather than the needs of each individual learner, though these too can be accommodated if the pedagogical design supports that." (p. 114). In that case, other resources are Web resources and either lessons conceived in advance. "It is the purpose of the online interaction to use the learners themselves as a ressource, and to build on their experience, reading and perspectives" (ibid, p. 112). Berge (1995) also promotes socio-constructivism learning and emphasizes that learners have to learn by themselves, by participating in the task, by using the resources which they need and by applying their own learning style. 
So, ICT based distance education offers a lot of new possibilities, but, in the same time, it involves a new definition and new roles for teachers, their role being divided into two distinct roles: the instructional designer and the tutor. Courses supports and contents are created by the instructional designer who is an expert on teaching area. Contents are then delivered to students often without any relation with the instructional designer. Tutors usually interact with learners to assist them in building knowledge and competencies and to assess them. A single person can play both roles, but each role does not intervene in the same moment of the course.

In literature, tutors are named differently, according to functions assigned to them: moderator, facilitator, online tutor, online moderator, e-moderator, coach, distance education mentor, etutor... It is thus very difficult to determine exactly tutors' role and what are the functions which are assigned to them. Furthermore, the support brought by tutors to learners requires them to adopt different roles depending on the type of learners' tasks (for example individual or collaborative work) (Denis et al., 2004). Lentell (2003, p. 74) states that "tutors need to have knowledge and a broad conceptual understanding of their field. They have to be effective listeners and communicators, to be a coach, facilitator, mentor, supporter and resource. They have to listen, to shape, to give feedback, to motivate, to direct, to appreciate - broadly to be developmental and problem solving." Denis et al. (2004), inside the Learn-Nett project, assign seven different roles to the tutor: a content, metacognition and process facilitator, an advisor/counsellor, an assessor, a technologist and a resource provider.

The implementation and the progress of distance learning activities are modified because they are mediated through a virtual environment. The literature reports difficulties of communication due to the distance and used tools. According to Feenberg $(1989$, p. 28$)$, the management of a group is "unusually complex because of the difficulty to manage an organized activity of a group in a written environment." Difficulties also appear at the interactions level between learning actors, which impacts on social links. To solve inherent difficulties of computer mediated communications, the role of moderator is a key to manage interactions. So, Feenberg (1989, p. 33) asserts that a strong leadership is needed to compensate for the lack of no verbal indications of communication. Mason (1991) also insists on the importance of a leadership and a directivity in interactions management, considering it as a sine qua non condition of the success of an electronic conference. According to Dillenbourg (1999), tutors are "facilitators" because they have to assure a minimal educational intervention to guide the learning group in a productive way.

Thorpe (2002, p. 105) also highlights the importance for the tutor to adapt learning situations to learners by taking into account their needs, their objectives and their learning styles: "the substance and the meaning of online activities is determined by the particular students who work together online. Their tutor may play a very direct role also, helping shape these interactions, sometimes designing the activities themselves in order to suit particular needs of the current group." According to Casey et al. (2005), teachers should be able, as they improve their educational expertise, to teach by adapting to circumstances and context in order to make possible students learning.

Hence, to sum up, tutors are asked to assume a lot of functions. They have to listen, to give feedback, to motivate, to guide learners, to organize group activities, to manage interactions and to adapt activities to learners. They also have to be coaches, content facilitators, mentors, advisors, assessors, technologists and resource providers. In this context, tutors work is not a simple activity because:

- The instrumentation of tutor activity in distance learning environments is still little developed (Dufresne et al., 2003).

- They have no means to monitor the change of their activities. It is necessary to make them aware that traditional tutoring cannot become "on-line tutoring" by modification or adaptation. It requires a fundamental restructuring.

About the first point, an important problem is that there is no trace of tutors' work (decisions taken, events that occured, scenario configuration or personalization, quality of the knowledge building process, etc.). Therefore there is no possibility of sharing practices and reusing them in other contexts. There are a lot of research on the characterization and the standardization of learning activities in order to assist instructional designers in scenario designing. But tutors prepare their own pedagogical contents for their students, and there is currently no possibilities of reusing and sharing them. Tutors do not use "reusable" content, usually named learning objects, because they would like to be able to have access to contextual information on resources to evaluate and reuse them.

As a result, tutors do not really know what they have to do and what the best way to do it is. According to Casey et al. (2005), ICT can improve pedagogical practices but the problem is that tutors do not always know how to use them in their educational activities (Michel et al., 2007): "There is a growing realisation that it is not very sensible to invest in learning technology and not change the way we work." For the course to be effective, Mc Pherson and Nunes (2004) insist on the importance of both tutor's role and instructional designer's role: “the focus is frequently placed on design and developing information and communication technology (ICT) based environments and insufficient attention is given to the delivery process. These efforts have little chance of 
succeeding without a tutoring team that has appropriate online tutoring skills necessary to explore and maximize the designed environments."

So, ICT not only changes the way students learn but also the way teachers work. We study how ICT can contribute to the recognition and definition of a specific role of tutor. Today it is advisable in education to ask the question of how ICT, having modified the teacher role, can now contribute to define it and help "tutors". So, our research purpose is to bring a solution to solve the problems for tutors defined in this section, which are:

- $\quad$ Lack of professional identity.

- $\quad$ Lack of help in their day-to-day practice.

- $\quad$ Lack of practice sharing.

\section{Tutors in a virtual community of practice}

Casey et al. (2005) assert that "good teaching [...] is reflective and reflexive about the experience of teaching and incorporates lessons learnt from the experience of teaching into teaching practice". Tutors must examine their own work. They also have to confront their ideas in order to determine "good practices", and so have the possibility to refer to these. These "good practices" will be a help to assume all the functions that we have enumerated in the previous section. According to the socio-constructivist approach of learning, collaboration between tutors can help each one to build new competencies and reinforce existing ones. That is why we suggest that tutors develop their competencies and define their work and good practices in the context of a community of practice. We now describe how this approach can contribute in solving all the problems previously defined.

\subsection{Virtual Communities of practice}

According to Wenger et al. (2002), communities of practice (CoPs) are "groups of people who share a concern, a set of problems, or a passion about a topic, and who deepen their knowledge and expertise in this area by interacting on an ongoing basis." They operate as "social learning systems" (Snyder et al., 2004) where practitioners connect to solve problems, share ideas, set standards, build tools, and develop relationships with peers. Organizations and researchers use a variety of terms which refer to CoPs: knowledge communities, knowledge networks, learning networks... In order to situate a CoP in reference to all these terms, Snyder et al. (2004) give a definition: "A community of practice is a particular type of network that features peer-to-peer collaborative activities to build member skills".

Other important aspects of CoPs are pointed out by Scarbough and Swan (1999): "Socially, CoP are the fabrics of knowing as members of CoP acquire communal identity around a shared passion, relationships, roles and ways of intermingling common knowledge, practices and approaches". This definition highlights the social aspect of CoPs. Members of a CoP, by interacting around a same subject, define common practices, and create identity which is common to all the members.

A virtual community of practice is a specific kind of $\mathrm{CoP}$, resulting from computer mediation. According to Koh and Kim (2004), a virtual community is "a group of people with common interests or goals, interacting for knowledge (or information) sharing predominantly in cyberspace." Relationships in virtual CoPs are now software mediated (e.g. forum, blog or wiki) generally classified by topic of interest. Fernback and Thompson (1995) pointed out the need for a virtual CoP to have "a specified boundary or place (e.g., a conference or chat line) that is symbolically delineated by topic of interest."

In the context of our study, we take up these main characteristics of virtual CoPs:

- Members share an interest, roles, a concern, a set of problems or a passion.

- They aim at building members skills and deepening their knowledge and expertise.

- Members acquire a common identity.

- $\quad$ They need a specified boundary or place.

- $\quad$ Practitioners define common knowledge, practices and approaches.

By putting these characteristics together, we notice that developing an environment to bring tutors to create a virtual CoP could be a solution to the problems highlighted in previous section. CoPs give the possibility for tutors from different backgrounds to define and acquire a professional identity, to share and develop their knowledge, competencies, expertise and to define "good practices" to apply in their work. But we now have to define the organization for a specific CoP of tutors, and the tools to support their interactions. 


\subsection{Tutors in communities}

There are tutors in many countries in the world and they all have their own practices and their own background. Tutors usually have another job and do tutoring as an "extra", along with their job. Some of them are teachers in university, researchers, and company employees... So they have different competencies and expertise to share with others and to acquire by participating in a CoP. According to Mc Pherson and Nunes (2004), for successful online learning, tutors must have subject matter expertise, technical skills, and also be educationalists with pedagogical, information and communication skills that are necessary to manage and facilitate online learning. But, due to their various backgrounds and the lack of training, only a few tutors have all these requirements. That is why it is important to favor the development of CoPs in which tutors will improve their expertise and competencies. Since "communities are emergent" (Brown and Duguid, 1991), we cannot "create" CoPs but we could provide the infrastructure in which they will emerge.

There exist several web-based CoPs of teachers limited by the borders of the institution to which they belong, generally supported by CMS (Course Management System) like Blackboard (West et al., 2006). Pashnyak and Dennen (2007) also study the case of a virtual CoP of teachers who share knowledge and exchange opinions with the support of blogs on a K-12 environment. In this case, the interactions are not limited to an institution but there are not supported by a specific environment for a virtual CoP. Ziovas and Grigoriadou (2007) showed, with the conduct of an experiment with three CoPs related to ICT (learners' community, researchers' community and teachers' community), that people can better introduce the practices of one community to another when they refer and negotiate the meaning of relevant boundary objects (ICT-based educational material served as the mediating objects around which members of the different practices crossed the boundaries of their communities and were brought into mutual engagement).

We base our work on the continuous process of negotiation of meaning introduced by Wenger (1998), which takes place in communities of practice and supports knowledge creation and learning. This process involves the interaction of two complementary processes: participation ("the social experience of living in the world in terms of membership in social communities and active involvement in social enterprises", p.55) and reification ("the process of giving form to our experience by producing objects that congeal this experience into 'thingness'”, p.58). In our research, we consider a global CoP of tutors as a constellation of interconnected CoPs (Wenger, 1998, p. 127), so as to support and amplify the process of knowledge creation by the negotiation of meaning in the boundaries of these CoPs. So we have to differentiate different types of CoPs of tutors and to determine the objects and the actors who will allow negotiation in the boundaries of these CoPs. So as to define different types of CoPs of tutors, we referred to the literature. Regarding, on the one hand, the tutor's role and, on the other hand, characteristics of CoPs, we distinguish three types of CoP of tutors (see Figure 1).

\subsubsection{Tutors who monitor the same type of activities:}

As we said previously, there are more and more various activities offered to learners in distance learning: project-based learning, case study... These activities can be divided into several distinct stages: for example individual or collaborative stages, distance or face-to-face stages... So, tutor functions vary according to these different types of stages. Communities can be created for tutors who supervise the same type of activity, in order to improve their practice and to share their experiences.

\subsubsection{Tutors who have the same function in a course:}

As we detailed in part 2, different functions are assigned to tutors according to on-line courses, training situations, kind of activities or university. In practice, a tutor does not assume all these functions and is not necessarily aware of each one, but as we develop a platform to support a global CoP of tutors, we have to consider all possible functions. We sum up these functions:

- An assessor: the tutor assesses the learning group's productions and activities, and the competencies and knowledge acquired by a learner.

- An intellectual catalyst: to incite learners to have individual reflection, to express themselves publicly and to develop their ideas.

- A moderator of interactions: the tutor develops and regulates interactions (Dillenbourg, 1999) and sets up the group dynamics.

- A psychological and emotional support: a human mediator to motivate, encourage, stimulate learners and create a friendly learning environment.

- A learning facilitator: for a given learning situation, tutors can provide documents or advise adapted resources to guide learners and give them feedback on the assessment. 
- A technical support: the tutor helps learners to get acquainted with tools and provides technical support in case of trouble.

- A pedagogical architect: tutor has scope to adapt the learning situations created by the instructional designer to learners' needs and characteristics.

\subsubsection{Tutors who teach the same subject matter:}

In order to develop their knowledge and competencies in their subject matter, it is important to provide tutors with topics. Furthermore, the tutor's role can vary according to the subject matter, e.g. computer science, humanities or corporate knowledge management.

Figure1 CoPs of tutors as a global community

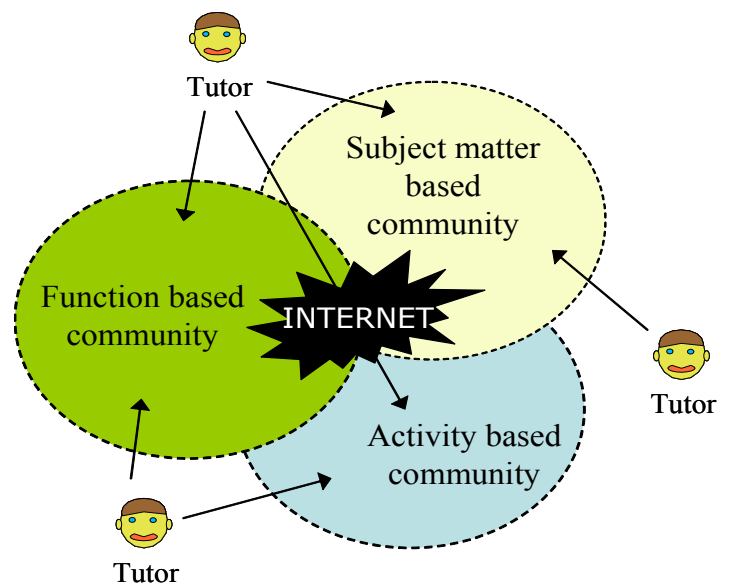

So, we can see that CoPs of tutors can be defined by a university or a company, they should be defined by common interests and common practices: "CoPs are important as they weave the organization around competencies without reverting to functional structures" (Pan and Leidner, 2003). A tutor can participate in a specific community or in two or three types of CoP. The advantage of defining several communities around shared practices is to create more knowledge and develop more interactions than in a global community (Pan and Leidner, 2003). Furthermore, within an organization perceived as a set of communities, not simply of individuals, separate community perspectives can be amplified by interchanges among communities (Brown and Duguid, 1991).

In next part, we present the TE-Cap (Tutoring Experience Capitalization) platform we developed. The development was based, on the one part, on our view of tutors' activities so as to determine functionalities they need on the platform and, on the other part, on results of interviews that we have conducted with several tutors in different institutions.

\section{Development of the TE-Cap platform}

\subsection{Requirements for a platform to support a virtual CoP}

According to a socio-technical approach, Koh and Kim (2004) distinguish two important points in order to develop CoPs: usability and sociability. Concerning sociability, William and Cothrel (2000) suggested three virtual community managing strategies: member development, community asset management and community relationship management. More specifically, a clear vision, opinion leaders, off-line activities, rules/roles, and useful contents based on expertise are required to run a virtual community intelligently. Preece (2001) highlights three components to support sociability of a virtual community: purpose (a community's shared focus on an interest, need, information, service, or support), people (interact with each other in the community and have individual, social and organization needs) and policies (language and protocols that guide people's interactions and contribute to the development of rituals that bring a sense of history and accepted social norms).

In addition to these common social characteristics of successful communities, Whitaker and Parker (2000) emphasize technology factors such as consistent and compatible software, which are very important in the context of a virtual community. According to Preece (2001), three usability components are particularly concerned with the software's role as a medium and a place for social interaction: dialog and social interaction support (the prompts and feedback that support interaction), information design (ease to read and understand information), navigation (ease to move around and find information) and access (requirements to download and run online community software must be clear). 
Pan and Leidner (2003) look at the use of information technology to link communities in order to create global knowledge sharing. They draw conclusions of the implementation of a Knowledge Management System (KMS) in a world company. They assure that it is important to create common knowledge CoP as opposed to a single global community or multi-region forum arrangement. They emphasize the need to provide multiple channels/forums for diverse knowledge sharing needs and preferences.

Von Krogh (1999) distinguishes three stages of KM: capturing knowledge, sharing and transferring knowledge, generating new knowledge. To overcome these stages, we suggest the TE-Cap platform to facilitate the capturing of tutors knowledge (their experiences, useful documents and Web links). The knowledge sharing and generating will be the result of the activity of CoPs. Since "the structural process that is associated with community is communication" (Fernback and Thompson, 1995), we need to provide to CoPs with the suited software to develop interactions.

To summarize, we can distinguish several requirements for a platform to support a virtual CoP of tutors, considered as a constellation of CoPs:

- $\quad$ Put forward a specific virtual space for each type of community (function, activity and subject matter communities), in which it can define its own identity, with subjects and vocabulary bound to the practice of the members.

- Offer tools to favor the exchange of knowledge across boundaries of communities.

- Facilitate the reflexivity of the members on their practices and lived experiences to develop their skills, knowledge and expertise.

- Facilitate the location of the sources of expertise and the skills identified within the community.

- Offer a tool to store all the knowlege produced by the global community, whether it is a result of interactions between peers (reflections, ideas, tools), or an individual contribution (testimony, document, interesting Web link).

- Offer a tool to search the stored information which can be relevant for members, in relation to their practice.

Considering these requirements, we compare them with the ones of Knowledge Management Systems (KMS) and Web 2.0 social software applications.

\subsection{Web 2.0 technologies : answer to the platform requirements}

$\mathrm{KM}$ systems are not convenient for a global $\mathrm{CoP}$ which is not limited by the borders of an institution or a company. CoPs are generally limited by the framework of the company they belong to and thus supported by KM systems developed by this company as presented by Piece and Leidner (2003). First, these systems are imposed by the company and it is the only means available for the employees to communicate and exchange. Secondly, these systems use Web tools to support the activities of the company in which CoPs members are already involved, whether it is within an organizational entity or beyond the organizational frontiers. In this case, members already have a feeling of membership in the company. But in our case, we address a global CoP of tutors who do not belong necessarily to the same teaching institution or university. The most important problem to solve is then to promote interactions between tutors out of any framework imposed by an organization. The main point is to make tutors aware about common needs and practices.

That is why we choose to develop a platform which rests on Web 2.0 principles and composed of existing Web tools available for communities like subscriptions, individual profile page, blogs, file sharing, document repository, presence indicator or member directory (Wenger, 2005). Some Web 2.0 applications like Facebook (http://www.facebook.com/) or MySpace (http://www.myspace.com/) are social networking services that "connect you with the people around you" but they are centered on members' identity or interests. Our platform aims at connecting tutors according to the context of their work, the functions they assume in the course or the subject matter in which they are experts, with the possibility to locate interesting sources of expertise and skills identified within the community. Furthermore, the purpose is not only to favor interactions but also to create a database on tutoring experiences. An experience could be what tutors set up in their course and whether it works or not. For example, a tutor can adapt difficulties to a specific learner and improve his/her learning quality. It must be an interesting testimony for other tutors.

TE-Cap is based on a principle that O'Reilly (2005, p. 3) states about Web 2.0: "Without the data, the tools are useless; without the software, the data is unmanageable". For him, every significant internet application to date has been backed by a specialized database: Google's web crawl, Yahoo!'s directory (and web crawl), Amazon's database of products, eBay's database of products and sellers... Like eBay, TE-Cap product is the collective activity of all its users (tutors); TE-Cap grows organically in response to users' activities. In order to support sociability and usability necessary for a $\mathrm{CoP}$ to live, the platform interface has to be adapted to the 
specific activity of tutoring. Existing applications only bring solutions for communities of interest where members do not come to look for very precise information. There are also commercial applications like e-Bay or Amazon where the search is precise but centred on a product.

We want tutors to store and retrieve resources (messages, useful documents and Web links) and especially experiences in the context they concern. But, to be effective, this action must be performed quickly, because tutors do not have enough time for this. That is why we have to design a simple interface easy to use and to learn as advised by Wenger (2005). O'Reilly (2005) also concludes on the importance to rich user interfaces: "We're entering an unprecedented period of user interface innovation, as web developers are finally able to build web applications as rich as local PC-based applications".

One of the important points of the interface is to make the vocabulary evolve as tutors use the platform. More and more Web applications use folksonomy (in contrast to taxonomy), "a style of collaborative categorization of sites using freely chosen keywords, often referred to as tags" (O'Reilly, 2005). Nevertheless, within the framework of a CoP of tutors, we consider the necessity to provide a classification to store data and, especially experiences. In this way, data could be retrieved in their context. Taging systems work well for communities of interest where users are going to navigate in the application with no very precise purpose in mind but it is not really adapted to a $\mathrm{CoP}$ where users look for ressources bound to work experiences. Therefore, we decided to develop a platform with an attractive human-computer interface allowing structuring without a too high rigidity.

\subsection{TE-Cap functionalities}

This part presents TE-Cap functionalities, which are detailed in (Garrot et al., 2007b). In the next section, we detail the interface used to store and retrieve experiences and other resources, which is in the heart of our approach of a global $\mathrm{CoP}$ of tutors as several interconnected communities. An experience could be what they set up in their course and whether it works or not.

\subsubsection{Members' profile and interactions support}

We showed previously the importance for a CoP to facilitate the location of the sources of expertise and the skills identified within the community. For that purpose, we make available on the platform the profile of each tutor, this one being composed of four parts:

- Identity profile (country, job, age...).

- Professional and university backgrounds (tutoring experience, training to be a tutor...).

- Profile in relation to the formation (disciplines, monitored training courses, institution or company...).

- Competencies (pedagogical, technical, subject matter expertise...).

The most important point is to allow a novice tutor to locate an intermediate or expert tutor whom he can ask for help. The mutual aid between the members of a $\mathrm{CoP}$ is one of the foundations for the skills development of everyone.

The platform offers two possibilities to support interactions:

- Sending an e-mail to a member of the community from its profile. So, if a tutor is interested in the profile of a member, he can choose to send him/her an e-mail for private communication. This tool allows getting in touch members and able to develop relations between peers outside the platform space.

- Writing a message with the possibility for the other members to answer. Before message validation, the writer has to indicate his/her "intention" when writing the message: testimony, ask for help or discussion. This choice brings the writer to think about the message content and so more generally to reflexivity on the practice of which $\mathrm{s} /$ he testifies. It is also an indication for other members that can direct their answer. After message validation, the writer is directed to an interface to classify the message according to several subjects, interface we present in detail in part 4.3.2. This tool has the same communication mode as forums but messages are classified in a more structured way, according to subjects associated with the community practices.

So, at this first cycle of development, we wished to offer only communication tools necessary to the interactions between members, by distinguishing a tool of getting in touch between peers and a tool to support exchange of experiences classified by subjects, according to writers' intention.

\subsubsection{Personal space for information management}

The platform offers diverse tools assuring creation, sharing and storage of the information brought or produced by the community. When tutors are connected, they can choose to manage their messages (see Figure 2), their documents or their Web links. For each of these features, the platform shows the list of the resources that a tutor 
has already proposed, the number of times they were viewed by the members of the community and the possibility is given to propose a new one. This conception of the platform allows tutors to manage the information they bring to the community, as well as the interest aroused by these on the other members (with the total number of access).

Figure 2 The personal space of messages publication

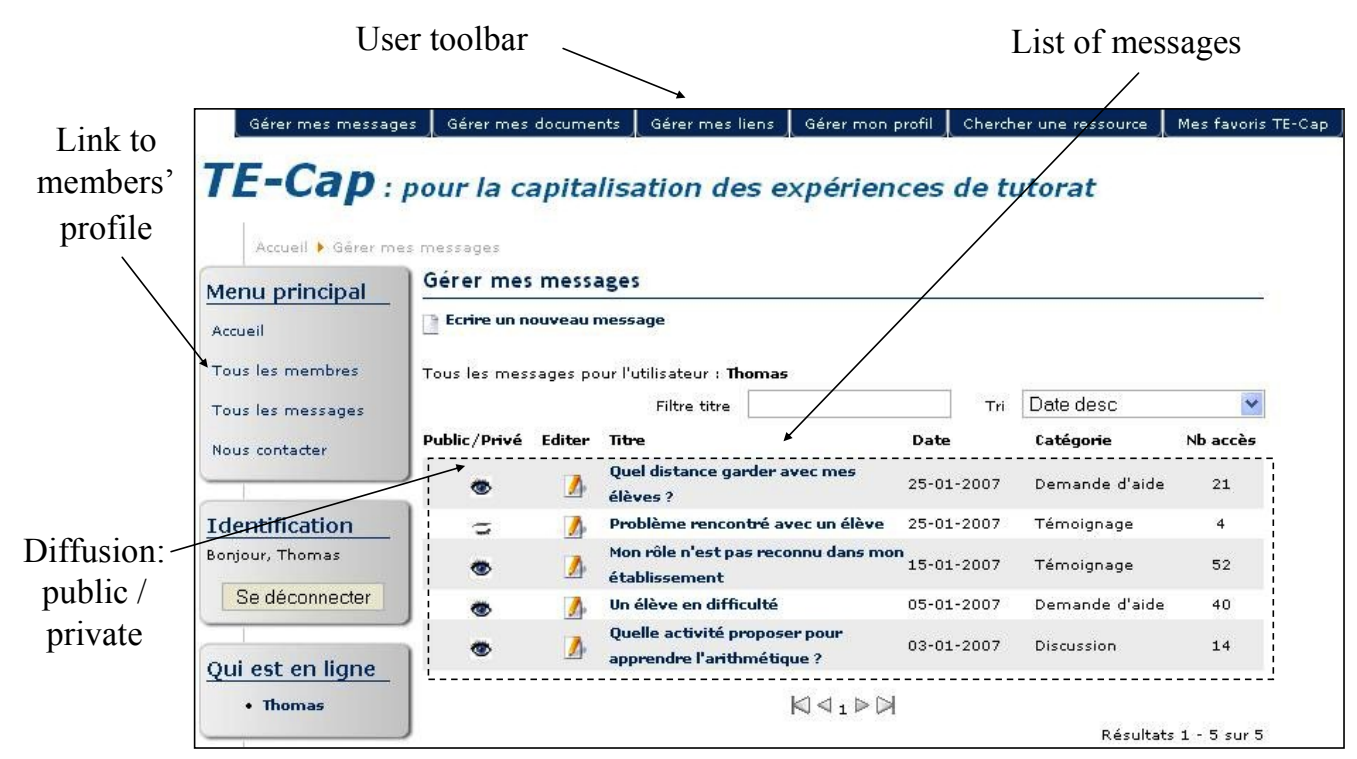

\subsection{Design of the interface for knowledge searching and retrieval}

\subsubsection{Evaluation by tutors of an early prototype interface}

We conducted interviews to get tutors opinion on an early prototype. The interface we designed on the shape of a matrix. We based the design of this interface on the three types of CoPs of tutors that we distinguish in previous part (function, activity and subject matter based communities). So, when accessing the interface, tutors could store experiences according to a function or a specific phase of the course (see Figure 3 ).

Figure 3 Experiences matrix per function per phase

\begin{tabular}{|c|c|c|c|c|c|}
\hline & & & Parameter & activities & \\
\hline & & $\begin{array}{c}\text { Problem } \\
\text { formalization }\end{array}$ & $\begin{array}{c}\text { Cause } \\
\text { searching }\end{array}$ & $\begin{array}{c}\text { Solution } \\
\text { proposition }\end{array}$ & $\begin{array}{c}\text { Solution } \\
\text { implementation }\end{array}$ \\
\hline & & $\begin{array}{l}\theta 0 \\
\square \leftrightarrow \square\end{array}$ & $\begin{array}{c}\underbrace{}_{0} \\
\square \leftrightarrow \square\end{array}$ & $\begin{array}{l}\because A 8 \\
\square \rightarrow \vec{E}\end{array}$ & $\begin{array}{l}\Leftrightarrow \\
\therefore \leftrightarrow \\
\square\end{array}$ \\
\hline & Assessor & 1 & 2 & 3 & 5 \\
\hline & Intellectual catalyst & 11 & 4 & 1 & 6 \\
\hline & Interaction moderator & 5 & 7 & 0 & 0 \\
\hline functions & Motivational support & 2 & $\triangle 6$ & 7 & 3 \\
\hline & Learning regulator & 5 & 10 & 4 & 0 \\
\hline & Technical support & 8 & 4 & 1 & 2 \\
\hline & Pedagogical architect & 1 & 5 & 0 & 0 \\
\hline
\end{tabular}

First line corresponds to the several phases of a course, which are parameterized activities. When accessing the matrix for the first time, the tutor determines parameters (illustrated in a cell) of each particular activity in his/her course:

- Individual $\Leftrightarrow$ or collective $\Leftrightarrow$ activity. 
- At distance

The first column of the matrix lists the different tutor's function which we previously present in part 3.2.2. Figure 3 illustrates a case study which has four activities. The tutor can click on different cells to store or search an experience. For example:

- (1) is a cell in the intersection of a column and a line. The tutor accesses experiences which correspond to the function of motivational support and the second phase of the case study (cause searching).

- (2) is a cell in first column. The tutor accesses all experiences linked to the motivational support function.

- (3) is a cell in first line. The tutor accesses all experiences related to the second phase.

The number into each cell indicates the number of experiences which correspond to a specific function and an activity type. Darker is the color of the cell, more there are stored experiences. So, with this matrix, tutors can store and access very quickly the experiences which concern them.

We conducted seven interviews with tutors of different institutions, with different backgrounds: 2 tutors from the FORSE campus of Lyon (educational sciences), 1 tutor from the FORSE campus of Rouen (educational sciences), 2 tutors from the VCiel campus (computer science), 1 tutor from DESS UTICEF (use of ICT in education and training) and 1 educator from GRETA of Lyon (training to set-up blended learning). We interviewed them about the interface we detailed previously. By analyzing transcription of interviews, we distinguished two types of results concerning the interface: one related to the matrix (division in functions and activities) and one related to our view of tutors as a constellation of three communities.

Concerning the matrix, several tutors raised the difficulty to classify an experience in a cell. We notice that they feel forced to have to fill all the cells whereas they do not think they can a priori put a lot of information inside: "I do not see what I could put inside in fact". More precisely, the division of the scenario in activities seems interesting because it requires less reflection about the situation. In fact, it reduces the complexity of the scenario and so it does not require a global approach of the whole scenario. But the division in several tutor functions is not relevant because tutors are not aware of all the functions that compose their role and particularly during an activity of the scenario. It requires taking too much back with regard to their day-to-day practice (it is not easy to say if an experience concerns a precise tutor function). Furthermore, it does not really have interest in it for tutors to know which role they play. To conclude, it seems to be easier to find information than to formulate an experience corresponding to a cell.

Tutors did not seem to be satisfied by the three types of tutors CoPs we distinguished (function, activity and subject matter based communities). In fact, they ask why only these three CoPs? For example, tutors have problems to solve concerning a particular type of learner (for instance, someone in difficulty in regards to the group) or relating to the institution to which they belong. So we thus questioned our division in three communities and we tried to see all the subjects in relation with the practice of tutoring. As a result, we realized a model of the factors in relation with a practice of tutoring, based on the vocabulary used by tutors during interviews (Garrot et al., 2007a). This model was adapted to conceive the interface of the TE-Cap platform to store and search experiences.

In conclusion, we can notice that the interface of the early prototype was too difficult to use by tutor in their practice, particularly to store their experiences. The matrix which constraints tutors to choose a cell is too precise and we have to give tutors more degrees of freedom. Furthermore, the three types of CoPs of tutors we distinguished seem not to be relevant: there can be other communities and those we identified are not maybe the most relevant. That is why we designed another intermediate interface, in order to determine the most relevant types of communities of tutors, in relation to their practice, and the most adequate interface in regards to results of the experiment.

\subsubsection{Intermediate interface of TE-Cap to store and search experiences}

For this experiment, we designed an intermediate interface in the shape of a dynamic tree view, with hierarchically classified subjects (see Figure 4). These subjects were identified during the interviews and the classification is based on a model of the factors in relation with a practice of tutoring. When using TE-Cap, a tutor accesses this interface in two cases:

- When sending a message, a document or a Web link. Tutor has to choose the corresponding subjects in the dynamic tree view. For example, if a tutor asks for help because s/he does not know how to react in front of a learner in trouble within a workgroup, s/he can check the box "In trouble" in the subject "Position inside the group" in the part "Concerned learners" (see Figure 4). 
- When searching for any resources relating to tutoring. As we detailed in the platform functionalities, a tutor can consult and add interesting resources found to his/her favourites. Furthermore, $\mathrm{s} / \mathrm{he}$ can choose to react to a message, to bring assistance or to pursue a discussion for instance.

Figure 4 Interface of TE-Cap to store and search resources

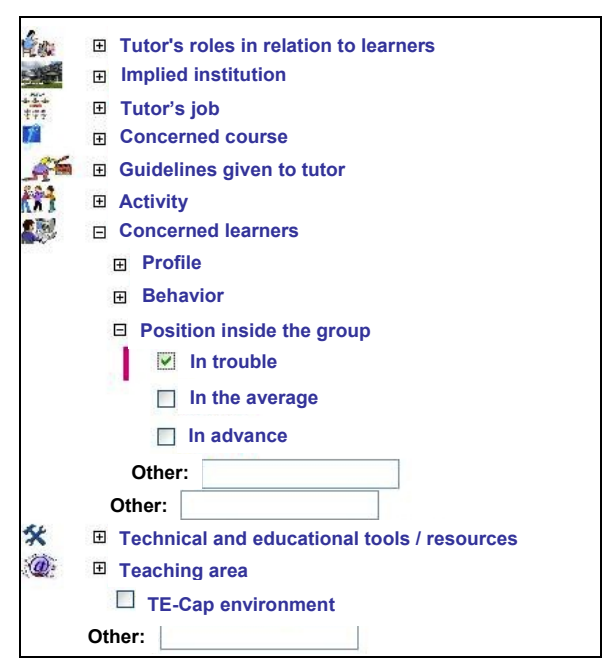

This intermediate interface is in the heart of the participative design of the TE-Cap platform. By experimenting this interface, we observe which categories (and how many) are chosen to store resources and which ones are chosen for the search. Tutors can also suggest new categories that are recorded, which allows for example to highlight useless ones. This approach aims at providing results about which types of communities of tutors we can distinguish (in regards to the categories chosen and suggested), and so design the final interface of the platform. Indeed, we aim at developing an interface which provides a space for each type of community.

\section{Experiment of TE-Cap and results}

The experiment provides qualitative information about the use of the platform, to evaluate its usability and utilisability. That is why this experiment involved the participation of no more than twelve tutors from six countries: Costa Rica, Senegal, Algeria, France, Tunisia and Canada. We chose tutors from different institutions and disciplines (e.g. educational science, computer science, mathematics, pedagogy, project management). They used the platform during two months and tried to integrate it into their practice. The experiment finished at the middle of 2007, March. We analyzed use traces by focusing on the response to tutors' needs in terms of tools to favor interactions and interface to store and retrieve information. The aim of the experiment is not to draw definitive conclusions. We just make hypotheses so as to make TE-Cap functionalities and interface evolve and thus to correspond to users behavior by using TE-Cap.

We observed subjects used by tutors to classify and search experiences, so as to determine the main domains concern by the tutoring practices. By observing categories used by tutors in the classification of the interface, we want to decide which types of communities are relevant. As a result, we notice the following behavior:

- There were fewer interactions than we supposed: only six messages posted and an average of three answers per posted message.

- When classifying a message, some tutors marked all the boxes (corresponding each to a main category). We suppose that they made this choice to be sure that their message would be retrieved and so read by the other members.

- In the opposite, some tutors marked only one box. We suppose that they did this so that the classification of the message would be fast. Maybe they chose a category because they were obliged to, but this category didn't seem to correspond to the posted message.

- Few supplementary categories were suggested (only two). Tutors mainly used the existing categories to classify their messages. We suppose that tutors do not take time in their practice to think about other categories.

- Only two tutors and only twice (once to classify a message and once to search) have clicked icons (+ sign) to see subcategories. This observation joins a previous result, which is that tutors do not spend time to find the categories which correspond best to their message testifying of an experience or to search interesting resources. 
- $\quad$ Few searches were made (eighteen only by three tutors). Our hypothesis is that tutors do not have time to spend in searching for information. They want to be informed of the last messages posted, last documents or Web links and last comments made on a message, without to have to connect to the platform.

In regards to the theory of CoP developed by Wenger (1998), we think we have privileged the reification of knowledge with regard to the participation of the community. We have not offered enough possibilities to access easily to these resources and to react on them. More precisely, the interface to search experiences was not adapted to tutors' activity. For example, tutor has to search for messages which have been posted so as to respond to them. So the link between reification and participation was not enough emphasized by this first prototype of the platform. The usability of the interface to classify and search resources is not enough adapted to tutors, so the interface has to be modified and improved.

We are currently making the platform evolve so as to better meet tutors' needs and particularly to increase members' participation. The development is directed in two axes: sending information directly to the community members to facilitate the participation (by using the syndication feed technology, i.e. RSS technology) and personalizing the interface to each tutor, according to the various types of $\mathrm{CoP} s /$ he wants to belong. This new prototype is currently be used in real conditions of use and either as an experiment, with a non limited number of participants.

\section{Conclusion and future direction}

We studied a new way to use ICT in education in order to help tutors to learn and develop competencies and expertise in the context of communities of practice. As members of CoPs, tutors can share their experiences and define good practices. All this knowledge was easily accessible through our platform which had few functionalities for a first experiment. The main aim was to observe tutors behavior with the offered functionalities and principally with the interface to classify and search experiences and other resources (messages, documents and Web links). We provided tutors with two different interfaces (one during interviews and the other for the experiment of TE-Cap) but none of them was totally adapted to their needs in the context of their activity.

As a result, we developed a new prototype of TE-Cap to improve tutors participation within the platform (by using RSS feeds). We also make the link between users profile and the interface by using AJAX which is a key component of Web 2.0 applications for rich user interfaces. The experiment results lead us to ask some questions: is it because tutors were all from different institutions that there were few interactions? Do interactions have to be born at a local level (i.e. institution) to raise then to a global level (beyond institutions) to come down again at a local level (in another institution)? The current experiment will address these questions.

\section{Acknowledgement}

The authors would like to thank tutors and colleagues for their participation in the experiment of the TE-Cap platform.

\section{References}

Berge, Z. L. and Collins, M. P. (1995). Computer-Mediated Communication and the Online Classroom in Distance Learning. Computer-Mediated Communication and the Online Classroom, Hampton Press (Cresskill, NJ), Vol. 3, No 3.

Brown, J.S. and Duguid, P. (1991). Organizational learning and communities of practice. Organization Science, Vol. 2, No 1, pp.40-57.

Casey, J., Brosnan, K. and Greller, W. (2005). Prospects for using learning objects and learning design as staff development tools in higher education. Proceedings of IADIS International Conference on Cognition and Exploratory Learning in Digital Age (CELDA 2005), Porto, Portugal, pp. 96-104.

Denis., B., Watland, P., Pirotte, S. and Verday, N. (2004). Roles and Competencies of the e-Tutor (Learn Nett project). Proceedings of Networked Learning Conference, England, Retrieved March 3, 2008 from http://www.networkedlearningconference.org.uk/past/nlc2004/proceedings/symposia/symposium6/denis_et_al.htm

Dillenbourg, P. (1999). What do you mean by 'collaborative learning'?. Collaborative-learning: Cognitive and Computational Approache. Eds. P. Dillenbourg, Oxford, Elsevier, pp. 1-19.

Doise, W., Mugny, G. and Perret-Clermont, A.N. (1975). Social Interaction and the development of cognitive operations. European Journal of social Psychology, Vol. 5, No 3, pp.367-383.

Doise, W. and Mugny, G. (1984). The Social Development of the Intellect. Pergamon Press, New York. 
Dufresne, A. Basque, J., Paquette, G., Léonard, M., Lundgren-Cayrol, K. and Prom Tep, S. (2003). Vers un modèle générique d'assistance aux acteurs du téléapprentissage. STICEF, Vol. 10, pp. 57-88.

Faerber, R. (2002). Le groupe d'apprentissage en formation à distance : ses caractéristiques dans un environnement virtuel. La place des TICE en formation initiale et continue à l'enseignement : Bilan et perspectives, E. L. F. K. T. Sherbrooke, pp.99-128.

Feenberg, A. (1989). The Written World: On the Theory and Practice of Computer Conferencing. Mindweave: communication, computers and distance education. Eds. R. Mason, \& Kaye, A. Oxford, Pergamon Press, pp. 22-39.

Fernback, J. and Thompson, B. (1995). Virtual communities: Abort, retry, failure? Proceedings of Annual Convention of the International Communication Association. Albequerque, NM.

Garrot, E., George, S. and Prévôt, P. (2007a). TE-Cap : une plate-forme support au partage et à la capitalisation d'expériences entre tuteurs. 3ème Conférence en Environnement Informatique pour l'Apprentissage Humain (EIAH 2007), Lausanne, Suisse, 27-29 Juin 2007, pp.185-196.

Garrot, E., George, S. and Prévôt, P. (2007b). The Development of an Assistance Environment for Tutors Based on a Participative Design Approach. 2nd European Conference on Technology Enhanced Learning (EC-TEL 2007), Lecture Notes in Computer Science, Springer, Crete, Greece, 17-20 September 2007, pp.481-486.

Houssaye, J. (1988). Théorie et pratiques de l'éducation scolaire (Tome 1-Le triangle pédagogique), Berne : Peter Lang.

Koh, J. and Kim, Y.G. (2004). Knowledge sharing in virtual communities: an e-business perspective. Expert Systems with Applications, Vol. 26, No. 2, pp. 155-166.

Lentell, H. (2003). The Importance of the Tutor in Open and Distance Learning. Rethinking learner support in distance education. Eds. A. Tait \& R. Mills, London: RoutledgeFalmer, pp. 64-76.

Mason, R. (1991). Moderating Educational Computer Conferencing, DEOSNEWS, Vol. 1, No 19, Retrieved March 3, 2008 from http://www.emoderators.com/papers/mason.html

McPherson, M. and Nunes, M. B. (2004). The role of tutors as an integral part of online learning support. European Journal of Open, Distance and E-Learning (EURODL), Vol. 1, Retrieved March 3, 2008 from http://www.eurodl.org/materials/contrib/2004/Maggie MsP.html

Michel, C., Garrot, E. and George, S. (2007). Instrumented Collective Learning Situations (ICLS) : the gap between theoretical research and observed practices. 18th International Conference on Society for Information Technology and Teacher Education (SITE 2007), San Antonio, Texas, USA, March 26-30, pp.895-901.

O'Reilly, T. (2007). What Is Web 2.0: Design Patterns and Business Models for the Next Generation of Software. O'Reilly Media. Retrieved March 3, 2008 from http://www.oreillynet.com/pub/a/oreilly/tim/news/2005/09/30/what-is-web20.html

Pan, S.L. and Leidner, D.E. (2003). Bridging Communities of Practice with Information Technology in Pursuit of Global Knowledge Sharing. Journal of Strategic Information Systems, Vol. 12, pp. 71-88.

Pashnyak, T.G. and Dennen, V.P. (2007). What and Why do Classroom Teachers Blog? Proceedings of IADIS Web Communities Conference (WBC 2007), Salamanca, Spain, pp. 172-178.

Piaget, J. (1978). Behavior and evolution (D. Nicholson-Smith, Trans.) New York: Random House.

Preece, J. (2001). Sociability and usability in online communities: Determining and measuring success. Behavior and Information Technology Journal, Vol. 20, No 5, pp.347-356.

Scarbrough, H. and Swan J. (1999). Case studies in knowledge management. Institute of Personnel Development, London.

Snyder, W., Wenger, E. and de Sousa Briggs, X. (2004). Communities of practice in government: leveraging knowledge for performance. The Public Manager, Vol. 32, No. 4, pp. 17-21.

Thorpe M. (2002). Rethinking Learner Support: the challenge of collaborative online learning, Open Learning, Vol. 17, No 2, pp. 105-119.

Von Krogh, G. (1999). Developing a knowledge-based theory of the firm. In a Conversation with Professor Georg von Krogh University of St. Gallen St. Gallen. Switzerland, Retrieved March 3, 2008 from http://www.dialogonleadership.org/vonKrogh-1999.pdf

Vygotsky, L. (1986). Thought and language. Cambridge, Massachusetts: The MIT Press.

Wenger, E. (1998). Communities of practice: Learning, meaning, and identity. Cambridge, U.K.; New York, N.Y.: Cambridge University Press.

Wenger, E., McDermott, R. and Snyder, W.M. (2002). Cultivating communities of practice. Boston: Harvard Business School Press.

Wenger E., White N., Smith J.D. and Rowe K. (2005). Technology for Communities. Guide to the implementation and leadership of intentional communities of practice. Work, learning and networked, CEFRIO, pp. 71-94, Retrieved March 3, 2008 from http://www.cefrio.qc.ca/english/pdf/Guide Final ANGLAIS.pdf

West, R.E., Waddoups, G. and Graham, C.R. (2007). Understanding the experiences of instructors as they adopt a course management system. Educational Technology Research and Development, Vol. 55, No 1, pp. 1-26.

Whitaker, V.M. and Parker, C.M. (2000). The factors enabling and inhibiting the development of agricultural Internet virtual communities: An Australian case study. Proceedings of the 8th European Conference on Information Systems, Trends 
in Information and Communication Systems for the 21st Century (ECIS 2000), Vienna, Austria, Retrieved March 3, 2008 from http://is2.lse.ac.uk/asp/aspecis/20000008.pdf.

William, R.L. and Cothrel, J. (2000). Four smart ways to run online communities. Sloan Management Review, Vol. 41, No. 4, pp. 81-91.

Ziovas, S. and Grigoriadou, M. (2007). Boundary Crossing and Knowledge Sharing in a Web-Based Community. Proceedings of IADIS Web Communities Conference (WBC 2007), Salamanca, Spain, pp. 11-17. 